DOI 10.18413/2312-3044-2019-6-2-125-132

\title{
Forum: The Elite and Society in the Russian Empire from Paul I to Nicholas II
}

\author{
Konstantin S. Kunavin \\ Derzhavin Tambov State University \\ 33 Internatsionalnaia st., 392000, Tambov, Russia \\ E-mail: kunavinks@gmail.com
}

\begin{abstract}
The author reflects on the elite and society in the late Russian Empire, in particular on the criteria for belonging to the elite; the mobility of the border between the elite and non-elite, and between different types of elites; the sources and mechanisms of elite replenishment; metropolitan and provincial elites; and related questions.
\end{abstract}

Keywords: elite, Russian Empire, eighteenth century, nineteenth century, early twentieth century

Copyright: () 2019 Kunavin, K. S. This is an open-access publication distributed under the terms of the Creative Commons Attribution License, which permits unrestricted use, distribution, and reproduction in any medium, provided the original authors and source, the Tractus Aevorum journal, are credited.

\section{Форум: Эмита и общество Российской империи от Павма I до Никомая II}

\author{
К. С. Кунавин \\ Тамбовский государственный университет имени Г. Р. Державина \\ 392000, Тамбов, ум. Интернациональная, 33, Россия \\ E-mail: kunavinks@gmail.com
}

\begin{abstract}
Аннотация. Автор размышияет об элите и обществе Российской империи. Среди вопросов для обсуждения - критерии принадмежности индивида или социальной группы к элите; условность и подвижность границы между элитой и теми, кто к ней не принадлежал, а также между разными типами элиты; источники и механизмы пополнения элиты; специфика столичной и провинциальной элит и иные вопросы.
\end{abstract}

Ключевые слова: элита, Российская империя, XVIII век, XIX век, начало $\mathrm{XX}$-го века

ISSN 2312-3044 | http://belsu-tractus-aevorum.ru 
Russian administrative and estate elite: determining the composition and criteria for an individual or social group to join the elite

The question of the composition and borders of the Russian (as well as any other) elite of the late eighteenth through early twentieth centuries is no less sociological than historical. Since the concept of "elite" was rather vague for contemporaries, modern researchers have the right to offer their own definitions of the phenomenon and its boundaries.

To clarify the concept of "elite," it is first necessary to abandon the positive connotations of this word. The elite, in this case, did not mean "best." Affiliation with this group simply implied the dominant position in the social hierarchy. The next step is to consider specific historical mechanisms that ensured the dominance of a certain group within the borders of the Russian Empire. This will make it possible, among other things, to determine to what extent the concepts of "administrative elite" and "estate elite" were identical in nineteenth-century Russia.

In official political discourse, beginning with the reforms of Peter the Great, the boundaries of the administrative and estate elite merged. State (civil and military) service was considered the only occupation worthy of a nobleman (Redin 2018, 137-155). On the other hand, the civil service opened the way for non-nobles to achieve the highest class status. ${ }^{1} \mathrm{~A}$ century later, Nicholas I further emphasized this idea by trying, on the one hand, to limit noble participation in public administration and, ultimately, to restrict the status of the state elite to the social elite (Liashenko 2015, 390), and on the other, to further compel the social elite into public service, expanding and strengthening the bureaucratic apparatus (recruited from the nobility) and contrasting it with the rest of the nobility (Mironov 2015, 426). Despite these efforts, the Table of Ranks transformed the status of the social elite from ascriptive to attainable through public service, and introduced an element of public administration into the relatively spontaneous (for the imperial power) process of social stratification. This concerned both upward and downward mobility (the cases of deprivation of state rights by decision of state authorities occurred in the nineteenth century). Thus, the state mechanisms of elite formation dominated the social ones, and the administrative elite dominated the estate elite despite some common features in both groups.

As a result, most of the ministers during the reign of Nicholas II, according to State Council member V. I. Gurko, "did not belong to either the noble or gentry class." He notes: "all were commoners, no one belonged to the nobility." According to S. V. Kulikov, by 1917 the raznochintsy (commoners) made up one third of the members of the State Council, one tenth of the ministers, one fifth of the ministers and directors of

\footnotetext{
1 Thus, in the early nineteenth century, the holders of XIV military and VIII civil ranks received the right to hereditary nobility, and despite the fact that this border reached VIII grade for the military and $\mathrm{V}$ grade for the civil rank during the nineteenth century, the underlying principle remained the same.
} 
departments, almost one third of the senators, one third of the governorsgeneral, governors and city governors, one fifth of the vice-governors, one tenth of the governors' chambers and excise tax managers, a quarter of the chairpersons of the chambers of courts and district courts, and one tenth of ambassadors and envoys (Kulikov 2007, 123). These raznochintsy became nobles through public service.

According to a number of definitions of the term "elite," one of its main qualities is the ability to craft institutions that support its exclusive position. ${ }^{2}$ For example, Pierre Bourdieu, in one of his articles dealing with the genealogy of the state (mainly in France), emphasized that legal and administrative structures formed simultaneously with the estate of lawyers, while the formation of the latter took place under strict self-control of its reproduction (Bourdieu 2007, 237).

In nineteenth-century Russia, it was the highest level bureaucrats who had the ability to make their positions exclusive. By the beginning of the twentieth century, "the highest bureaucracy became self-sufficient in relation to the emperor. It did not depend on him, but he depended on it" (Kulikov 2004, 400). Such privilege by Russian officials was not unique. Any monarch who sought to strengthen his power was dependent on the means of its implementation, that is, on the bureaucracy (Volkov 2018, 83). It can be said that under any bureaucratic absolutist regime, the class elite gave way to the administrative elite. Thus, in relation to the Russian elite of the late eighteenth through early twentieth centuries, it is well worth keeping mind the state elite (which was only partly similar to the social elite) in mind in the nineteenth century.

Now we turn to the boundaries of state (or administrative, which we consider synonymous in this context) elites. Obviously, public service as the initial marker is insufficient due to the extensiveness of this category. A small provincial official who did not claim elite status was a civil servant nonetheless. However, contemporary ideas about ranks and the procedures of official promotion allow us to introduce a border separating the elite officials from the non-elite.

The so-called "generals' ranks" were located in the Table of Ranks from grade IV and above. In addition, a peculiar symbolic border passed between classes V and IV. Up to class V inclusively, the length of service rules was observed, which ensured that officials moved up the hierarchy regardless of their efforts. Promotion to class IV and higher occurred only through imperial decree for almost the entire nineteenth century

\footnotetext{
${ }^{2}$ E.g. the political view of O. V. Kryshtanovskaia: "The elite is the ruling group of society, which is the top stratum of the political class. The elite stands at the top of the state pyramid controlling the main strategic resources of power, making decisions at the national level. Not only does the elite rule society, but also governs the political class, and also creates such forms of state organization where its position becomes exclusive. The political class forms the elite and at the same time is the source of its replenishment" (Kryshtanovskaia 2004, 26-27).
} 
(Zaionchkovskii 1978, 36, 60). ${ }^{3}$ According to official statistics, by the end of the nineteenth century there were 160 thousand class civil servants in Russia, of which less than 1.5 percent belonged to the first four classes (Andreeva 2008, 668). Finally, "in accordance with the prevailing practice $<\ldots>$ the post of minister, for example, belonged to class II, the comrade of the minister-to class III; director of the department (administration), governor and mayor-to class IV" (Shepelev 1999, 172).

Thus, as the main criterion for an individual to join the elite, one can propose class IV or higher in the Table of Ranks.

Conventionality and mobility of the border between the administrative and estate elites

Despite the radical changes that took place in nineteenth-century Russia during modernization, the borders of administrative and estate elites were not sufficiently mobile. As previously noted, the number of noblemen increased as new families were granted noble status. However, it should be repeated that the former raznochintsy received official noble status. As a result, the dominance of the nobility in state policy not only persisted, but even increased. Throughout the nineteenth century the policy of the authorities toward the dominant estate group did not change. The Code of Laws of the Russian Empire that established this status quo (since 1833) was not revised until the beginning of the twentieth century, and the complete abolition of the estates with their privileges and obligations only occurred in 1917.

The borders of the state elite, despite external immobility, still trended weakly toward expansion. For example, since the end of the nineteenth century, the process of incorporating not only senior officials into real state administration persisted. Modernization meant that the qualifications of the highest bureaucrats in some narrow issues could be insufficient. In the government, measures were discussed that made it possible for people who had no rank to take high positions in public service. In contrast to the noble title, it was impossible to simply assign the desired rank to the right person, bypassing the long process of promotion in the Table of Ranks; the case of Sergei Witte was an exception. In 1894, the Ministry of Finance was given permission to fill all posts up to class V by persons previously involved in public service (Shepelev 1999, 187).

The second process, which expanded the boundaries of the state elite, was interrupted by revolutionary events, but it is also worth mentioning. It involved the emergence of the political (not state) elite in connection with the formation of parliamentarism, which had hypothetical chances to evolve into real participation in government. ${ }^{4}$

\footnotetext{
3 In November 1894, the specially established Imperial Department began to deal with the assignment of class IV, leaving for the Tsar to decide about classes from III to I (Zaionchkovskii 1978, 65).

${ }^{4}$ On the difference between the political and state elites see Protasov 2004.
} 
Sources, ways and mechanisms of elite replenishment

The nobility as the main source for replenishment for the state elite requires some clarification. The author, as part of his dissertation thesis, studied the factors that ensured the effective promotion of a candidate in the Table of Ranks. ${ }^{5}$ The study sample included all members of the State Council who began their careers during the reigns of Nicholas I and Alexander II (1826-81), a total of 271 people. The focus on successful bureaucrats was meant to answer the question: what factors ensured a competitive advantage among other successful bureaucrats?

Using mathematical methods, each person was assigned an index of their success (relative to other members of the sample). The index was based on the idea that the sooner a person received one or another rank, the more successful their promotion. Next, a series of correlation analyses were performed between the obtained index and various biographical factors.

The resultant analysis determined that neither the difference in origin (non-noble, noble, various ranks of the titled nobility), nor the position of the person's father in the state and royal court structures mattered among competitors for the status of the highest bureaucracy. The only factor that demonstrated a statistically significant but weak correlation $(\mathrm{v}=0.3$, $\mathrm{p}<0.01$ ) was education.

Further analysis showed that career success was influenced by the elite status of the educational institution rather than its rank. Thus, the Imperial College of Law, which integrated its graduates into the system of state power by default, turned out to be the most productive. ${ }^{6}$ Strange as it may seem, universities imparted a much lower career growth to their graduates than gymnasiums (even though a university graduate could immediately receive rank X). This suggests that, firstly, those who were more oriented toward a civil service career preferred to graduate from the gymnasium and start growing directly in bureaucratic structures rather than spend time at the university, and, secondly, networks of personal acquaintances that were formed within the walls of elite educational institutions contributed to further career growth. The latter fact suggests that in the second half of the nineteenth century the highest bureaucracy had the beginnings of corporate organization.

Thus, in spite of the fact that noble origin was an unconditional ticket to privileged educational institutions and universities, in the environment of a successful bureaucracy this factor no longer mattered and corporate mechanisms severed from the estate came to the fore.

Metropolitan and provincial elites: unity in diversity

An analysis of the provincial elite according to the abovementioned criteria presents some challenges. The empire's uniform system of ranks

\footnotetext{
5 Kunavin 2017.

6 According to $\$ 17$ of the School Charter, a graduate was required to serve at least 6 years under the authority of the Ministry of Justice (Annenkova 2006, 41).
} 
meant that the privy councilor remained the same everywhere in the country. No geographical criterion existed. Even the capital official did not have fundamental advantages over his provincial colleagues. In regard to equality of ranks, seniority was determined not by belonging to a particular government structure or royal court and not by the categories of "capital" or "provincial," but exclusively by the length of tenure held in rank.

Nevertheless, it is worth noting that the metropolitan service provided significantly more career opportunities for reaching the top four ranks. The officials themselves were well aware of this fact: "The desire to serve in the capital led to the emergence of 'out-of-staff' officials who, as a rule, served 'without salary...'. An attempt by the government to regulate the number of such employees did not create the desired results. The rescript 'On reducing the number of officials in ministries to eliminate extra staff and redundancies' (1812) led only to their partial reduction" since the ministers were self-interested in maintaining the status quo (Pisarkova 1995, 132-133).

Moreover, this situation again emphasized and strengthened the value of corporate mechanisms, as "it was difficult to get a full-time position in St. Petersburg, even with the support of influential people. By the middle of the nineteenth century, with the increase in the number of officials and their repeated redundancies, it was next to impossible to settle in the capital" (Pisarkova 1995, 136).

As for the provincial social structure, which could have given rise to a local social elite (provincial nobility) as a kind of opposition to the state elite, this had little effect, at least within the geographic boundaries of the province. Firstly (especially before the introduction of zemstvos), as T. Skochpol, a researcher of social revolutions in a number of countries, has emphasized: "Often their [nobles' $-K$. $K$.] possessions were not concentrated in one locality or even in one province, but were scattered across various regions of the empire. Under such conditions, local and regional solidarity could hardly develop among the nobles" (Skochpol 2017, 169). Moreover, even the introduction of zemstvos and the emergence of a number of joint social practices among participants did not allow them to successfully confront the state elite within the institution, although such circumstances did partly unite the provincial nobles. Zemstvos existed "side by side with, rather than within the hierarchy of political power in society." Thus, "the imperial authorities maintained a monopoly on control and coercion" (Skochpol 2017, 175).

The role of education, culture and science in the evolution of the elite

Current research indicates that since the evolution of the elite in the late eighteenth though early twentieth centuries is inextricably linked with the evolution of the highest bureaucracy, it is possible to draw conclusions about this phenomenon. Indeed, there are currently many scholarly works that touch on the educational and cultural level of top Russian officials in 
this period. Several researchers have concluded that throughout the nineteenth century the educational and professional level of top bureaucrats grew steadily. For example, I. V. Ruzhitskaia, applying the concept of "enlightened bureaucracy" to such officials, indicates that by the end of Nicholas I's reign, there was a significant layer of such statesmen. They provided the human capital that made the reforms of the 1860-70s possible (Ruzhitskaia 2009). It is worth adding that for the most part, the same people carried out the adjustments to the reforms under Alexander III. This seeming contradiction rather reflects the positive aspect of senior officials as a manifestation of governmentalism and professionalism. In sum, by the beginning of the twentieth century the Russian official was approaching the ideal Weberian model of rational bureaucracy.

Translated from Russian by Alexander M. Amatov

\section{References}

Andreeva, E. A., comp. 2008. Upravlencheskaia elita Rossiiskoi imperii: Istoriia ministerstv, 1802-1917 [The Administrative Elite of the Russian Empire: History of Ministries, 1802-1917]. St. Petersburg: Liki Rossii, 2008. (In Russian)

Annenkova, E. A. 2006. Imperatorskoe Uchilishche pravovedeniia [Imperial College of Law]. St. Petersburg: Publishing House Rostock. (In Russian)

Bourdieu, P. 2007. "Dukh gosudarstva: genezis i struktura biurokraticheskogo polia [The Spirit of the State: the Genesis and Structure of the Bureaucratic Field].” In P. Bourdieu. Sotsiologia sotsial nogo prostranstva [Sociology of Social Space], trans. from French by N. A. Shmatko. P. 220-254. St. Petersburg: Aleteia. (In Russian)

Kryshtanovskaia, O. V. 2004 "Sovremennye kontseptsii politicheskoi elity i rossiiskaia praktika [Modern Concepts of the Political Elite, and Russian practice." Mir Rossii 4: 3-39. (In Russian)

Kulikov, S. V. 2007. “'Revoliutsii neizmenno idut sverkhu...' Padenie tsarizma skvoz' prizmu elitistskoi paradigmy ['Revolutions Invariably Come from Above ...' The Fall of Tsarism through the Prism of the Elitist Paradigm]." Nestor 9: 115-183. (In Russian)

Kulikov, S. V. 2004. Biurokraticheskaia elita Rossiiskoi imperii nakanune padeniia starogo poriadka (1914-1917) [The Bureaucratic Elite of the Russian Empire on the Eve of the Fall of the Old Order (1914-17)]. Ryazan. (In Russian)

Kunavin, K. S. 2017. Career Growth Factors for the Highest Bureaucracy of the Russian Empire in 1830-80s. Kand. ist. nauk Diss. Tambov, Derzhavin Tambov State University. (In Russian)

Liashenko, M. I. 2016. "Reformy vtoroi chetverti XIX v. [Reforms of the Second Quarter of the Twentieth Century]." In Reformy $v$ Rossii $s$ drevneishikh vremen do kontsa XX $v$. [Reforms in Russia from Ancient times to the Late Twentieth Century]. In 4 vols. Vol. 2. Moscow: Political Encyclopedia. (In Russian) 
Mironov, B. N. 2015. Rossiiskaia imperiia: ot traditsii $k$ modernu [Russian Empire: from Tradition to Modernity]. In 3 vols. Vol. 2. St. Petersburg: Dmitrii Bulanin. (In Russian)

Pisarkova, L. F. 1995. "Rossiiskii chinovnik na sluzhbe v kontse XVIII - pervoi polovine XIX veka [Russian Official in the Service in the Late Eighteenth through the First Half of the Nineteenth Century]." Chelovek 3: 121-139. (In Russian)

Protasov L. G. 2004. "Mirazhi i deistvitel'nost' poloticheskoi modernizatsii v Rossii v XX veke [Mirages and the Reality of Political Modernization of Russia in the Twentieth Century]." In Rossiskaia imperiia: strategii stabilizatsii $i$ opyt obnovleniia [Russian Empire: Stabilization Strategies and Experience of Renewal]. Voronezh: Voronezh State University Press. (In Russian)

Redin, D. A., ed. 2018. Granitsy i markery sotsial'noi stratifikatsii Rossii XVII-XX vv.: vektory issledovania [Borders and Markers of Social Stratification of Russia of the Seventeenth through Twentieth Centuries: Research Vectors]. St. Petersburg: Aletheia. (In Russian)

Ruzhitskaia, I. V. 2009. Prosveshchennaia biurokratiia. 1800-1860-e gg. [Enlightened Bureaucracy, 1800-1860s]. Moscow: Institute of Russian History of the Russian Academy of Sciences. (In Russian)

Shepelev, L. E. 1999. Chinovnyi mir Rossii: XVIII - nachalo XX v. [The Officialdom`s World of Russia: From the Eighteenth through Early Twentieth Century]. St. Petersburg, Art-SPB. (In Russian)

Skochpol, T. 2017. Gosudarstva $i$ sotsial nye revolutsii: sravnitel nyi analiz Frantsii, Rossii i Kitaia /State and Social Revolution: A Comparative Analysis of France, Russia and China], trans. from English by S. Moiseev; scient. ed. by D. Karasev. Moscow: Publishing house of the Gaidar Institute. (In Russian)

Sobko, E. M. 2007. Gosudarstvennyi sovet v epokhu Aleksandra III [The State Council in the Era of Alexander III]. Moscow: MGUKI Press. (In Russian)

Volkov, V. V. 2018. Gosudarstvo, ili tsena poryadka [State, or the Price of Order]. St. Petersburg: Publishing House of the European University in St. Petersburg. (In Russian)

Zaionchkovskii, P. A. 1978. Pravitel'stvennyi apparat samoderzhavnoi Rossii $v$ XIX $v$. [The Government Apparatus of Autocratic Russia in the Nineteenth century]. Moscow: Mysl'. (In Russian)

\section{About the author}

Konstantin S. Kunavin, Candidate of Science in History, is senior lecturer in the Department of General and Russian History at Derzhavin Tambov State University.

This paper was:

received on September 30, 2019

accepted for publication on October 14, 2019

published online in English translation on February 21, 2020 